the general position, attitudes, or knowledge of some major segment of the profession, as distinguished from the personal views of the author, varies from paper to paper. But the collection as a whole reflects the profession of librarianship as a dynamic one, aware of important obligations and concerned with finding the best solutions.-Herman $H$. Fussler, University of Chicago Library.

\section{Methods of Research}

Methods of. Research: Educational, Psychological, Sociological. By Carter V. Good and Douglas E. Scates. New York, Appleton-Century-Crofts, I954. xx, 920p. \$6.00.

"This book has been written for field workers, graduate students, and members of the senior division of the undergraduate college who would evaluate the quality of conclusions, either as producers or consumers of research." This is the first sentence of the preface of this volume by Drs. Good and Scates, who represent two-thirds of the writing team which produced the useful The Methodology of Educational Research. The new volume is a more detailed analysis of methods in research on a wider scope than the work of Good, Barr, and Scates. Librarians, library school students, and members of library school faculties should find it a most helpful guide. As the authors further point out in the preface, the work is not intended to be a "recipe book," "cookbook," "rule book," or a series of "lesson plans" for problemsolving. Rather, it discusses concepts, principles, and procedures in educational, psychological, and sociological investigations.

Although the entire volume will be of interest to librarians, chapter 3, "Survey of Related Literature and Library Technique," and chapter 5, "The Descriptive Method: Classification," are worth particular attention. Chapter 3 emphasizes the need of searching the literature prior to starting on a new investigation, and, within the subject limits of the volume, suggests the many bibliographical and other aids useful to the researcher. In some instances, the detail is unusually full. For example, specific topics treated in the Review of Educational Research are traced in the various issues of the journal (pp.136-37). It is perhaps understandable that the authors would be intrigued by the "automatic elec- tronic library" described by Fred L. Walker in the Scientific Monthly for February, $195 \mathrm{I}$. Some attention is also given to national and international cooperation in library service, but, except for a number of citations to library literature, there is no discussion of the part played by subject specialists and reference librarians in assisting researchers.

Librarians will find chapter 5 a provocative discussion of classification as a fundamental basis of research. While the problems of classification in a research study are of a different order than those in organizing a library collection, the authors call attention to the several library classifications and lists of subject headings which are suggestive to students in the pursuit of their investigations.

Chapter 10, "The Reporting and Implementing of Research," summarizes in concise form the steps that should be familiar to research librarians. Included are details of presentation of data, bibliographical and footnote form, and style. Librarians who are interested in reporting on projects or writing for the library journals should find this discussion instructive.-Maurice F. Tauber, Columbia University.

\section{Junior College Books}

\section{Books for Junior Colleges: A List of 4000} Books, Periodicals, Films and Filmstrips. Compiled by Frank J. Bertalan. Chicago, American Library Association, 1954. 321 p. $\$ 7.50$.

Here is the long awaited and much needed list that will be helpful to all junior college libraries. Since Mohrhardt's list appeared in 1937, and many of its entries are now out of print or out of date, librarians and teachers of junior colleges have been requesting a current compilation. Entries in Mohrhardt's list were not included here unless they had been revised or enlarged.

This volume represents the work of junior colleges all over the country, the American Association of Junior Colleges, the American Library Association and its Junior College Section of the Association of College and Reference Librarians, the United States Office of Education and a few senior colleges.

The subjects included and the number of titles in each area were based upon an analysis of I 5 junior college catalogs, and the advice 
of the Curriculum Committee of the American Association of Junior Colleges. Devotees of the Mohrhardt list will be pleased to find that films and filmstrips accompany their respective subjects.

The 4052 entries are distributed as follows: Biology, 201 ; Business, 233; Classics, I6; Economics, 177; Education, 91; English, 319; Fine and Applied Art, 22I; Foreign Languages, 159; General Works, I 73; Health and Physical Education, I23; History, 309; Home Economics, 205; Mathematics, 98; Music, I85; Nursing Arts and Public Health, 58; Philosophy, 7I ; Physical Sciences, 259; Political Science, 149; Psychology, 143; Religion, 85; Sociology, 152; Speech and Dramatics, I 76 ; and Vocational and Technical Arts, 449.

Within each main area, there are included important divisions of that subject: i.e., Biology includes General Biology, General Botany, General Zoology, Fresh Water and
Marine Biology, Anatomy and Physiology, Bacteriology, Embryology, Genetics and Heredity, Vertebrate Zoology, Invertebrate Zoology, Ornithology, and Fish, Amphibia and Reptiles.

Titles were not repeated in related subjects due to restrictions in space and budget. Therefore it becomes necessary for users of this material to consult the index frequently since the compiler found it difficult sometimes to select categories for certain titles which relate to several classifications.

Bertalan's Books for Junior Colleges provides a splendid checklist for librarians to employ with their faculties when ordering materials. As new titles appear, as new subjects make greater impressions on the curricula, revisions will be necessary. However, for the mid-fifties it will be invaluable. Thelma V. Taylor, Los Angeles Harbor Junior College Library.

\section{A Century And A Half of Bookbinding Craftsmanship}

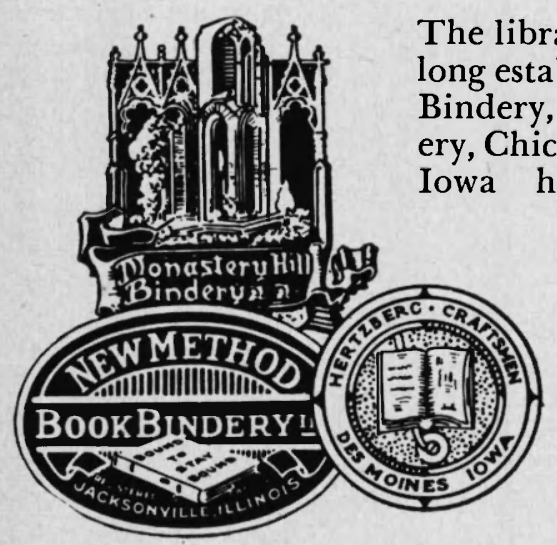

The library bookbinding departments of three of America's long established library bookbinders.... New Method Book Bindery, Inc., Jacksonville, Illinois-Monastery Hill Bindery, Chicago, Illinois and Hertzberg Craftsmen, Des Moines, Iowa have been acquired by HERTZBERG-NEW METHOD, INC. to bring you the very finest in library bookbinding services.

We will be glad to supply, without obligation, our "Speedy Service" Kit, containing helpful information for preparing your binding shipments. Send for this "Speedy Service" Kit today!

\section{HERTZBERG-NEW METHOD, INC. JACKSONVILLE, ILLINOIS}

